Philipp Asen

University of Applied Sciences

FH Joanneum Graz, Austria

philipp.asen@fh-joanneum.at

Vito Bobek

University of Applied Sciences

FH Joanneum Graz, Austria

vito.bobek@fh-joanneum.at

Tatjana Horvat

University of Primorska, Faculty

of Management, Slovenia

tatjana.horvat@fm-kp.si

\section{The Efficiency of Ports}

and Airports in Emerging Markets

Measured by Key Performance

Indicators: The Case of Hong Kong and Durban

Ports and airports impact emerging countries' development. A case study where the ports and airports of Durban, South Africa, and Hong Kong are compared should provide information about this issue. The research was based on a quantitative and descriptive approach, as the outcome was simply expressed in an overall summary. The results were that Hong Kong outperforms Durban in most key performance indicators such as revenue, cargo handled, or container dwell time. In addition, Durban's port is more expensive and cannot attract the most prominent businesses. However, even though Durban is nowhere near the size of Hong Kong, the port and airport are essential for their economy, and they keep improving. In conclusion, it can be said that some obvious factors influence the economy, like the size of the port or airport. Other than that, some indicators are not influenced by the size, like average turnaround time, which can be optimized.

Keywords: infrastructure development, importance of ports and airports, comparison of emerging countries, key performance indicators

Učinkovitost pristanišč in letališč na hitrorastočih trgih, merjena s ključnimi kazalniki uspešnosti: primer Hongkonga in Durbana

Pristanišča in letališča vplivajo na razvoj hitrorastočih gospodarstev. Študija primera, v kateri primerjamo pristanišča in letališča Durbana (Južna Afrika) in Hongkonga, bi morala zagotoviti informacije o tem vprašanju. Raziskava je temeljila na kvantitativnem in deskriptivnem pristopu, saj je bil rezultat preprosto izražen v splošnem povzetku. Rezultati so pokazali, da je Hong Kong boljši od Durbana pri večini ključnih kazalnikov uspešnosti, kot so prihodki, pretovorjen tovor ali čas zadrževanja zabojnikov. Poleg tega je pristanišče Durban dražje in ne more pritegniti najvidnejših podjetij. Čeprav Durban po velikosti ni primerljiv s Hongkongom, sta pristanišče in letališče ključnega pomena za njihovo gospodarstvo in se nenehno izboljšujeta. Ugotovimo lahko, da nekateri očitni dejavniki, kot sta velikost pristanišča ali letališča, vplivajo na gospodarstvo. Velikost pa ne vpliva na nekatere druge dejavnike, kot je na primer povprečni čas obdelave, ki ga je mogoče optimizirati.

Ključne besede: razvoj infrastrukture, pomen pristanišč in letališč, primerjava držav v vzponu, ključni kazalniki uspešnosti

(cc) BY-SA

https://doi.org/10.26493/1854-4231.16.75-81

\section{Introduction}

Goods and services get imported from abroad for different reasons: they may be cheaper, have better quality, or no local alternative is available or exists. Trade benefits may be inequitable, but some trade is better than no trade at all ('Interna- 
tional Trade: Need, Benefits, and Disadvantages' n.d.). Especially in the emerging economy, transportation costs can represent a significant barrier to trade, as the necessary infrastructure is non-existent, which means that the expansion of infrastructure could facilitate trade by increasing regional and international trade through reducing costs. In emerging countries, a significant reason for the low quality of infrastructure is poor maintenance because of limited financial resources (Soobramanien and Zhuawu 2014). However, efforts are made to improve transport infrastructure and its quality, as it is essential to a country's development and has a significant impact on the economy.

During the 19th century and first half of the 2oth century, ports tended to be instruments of state powers, and port access was regarded as a means to control markets. Competition between ports was minimal. However, times have changed, and most ports today are competing with each other on a global scale and, with the tremendous gains in productivity in ocean transport achieved over the past several decades, ports are now perceived to be the remaining controllable component in improving the efficiency of ocean transport logistics (Rodrigue 2020). So the three main determinants for competitive ports, identified here, are extensive maritime forelands (on the sea/water), effective port operations, and strong hinterland connections (road/rail) (Zhang and Roe 2019). The same can be said about airports. They have traditionally been considered as public utility providers, with little potential to develop significant market opportunities. Liberalization of the air transport market around the globe has introduced new dynamics into the airport industry. The emergence of competition and the transition in ownership (towards privatization or commercialization) demands a different perspective (Jimenez, Claro, and Pinho de Sousa 2014)

The maritime and air transport industry is cost-driven, e.g. if a vessel spends more time waiting outside the port for the next available berth or due to congestion, the cost of transportation of the cargo increases (UNCTAD 2014). Container ports and airports are compelled to regularly review their capacity and other Key Performance Indicators (KPIS) to ensure that they can provide satisfactory service to users and maintain their competitive edge.

This paper is about the efficiency of ports and airports and their role in emerging markets. In- frastructure has always been an essential tool for a country's wealth and growth, enabling Europeans to import goods from Asia faster or explore other parts of the world like the American continent (Beckmann 2019).

In the past, many countries defined themselves by their ports, in particular those with a vast port quickly becoming the linchpin for business worldwide. Connectivity attracts business investments and human capital, which means that ports and airports are significant drivers of a country's economic and social development. These ports give access to foreign markets, facilitate the movement of products and goods and make people mobile (Bjorndal 2017). However, the ports of Hamburg or Rotterdam are bigger and more successful than those of emerging countries. The same can be said about the airports in Atlanta or Frankfurt, which are well known, and every major airline heads for those airports (Roddey 2020; White 2018). Therefore, the paper highlights what the main drivers are for successful ports and airports and how they influence the development of a country.

Economically developing countries usually do not have a well-developed infrastructure as regards ports and airports. However, they are often located on essential trade corridors or are rich in natural resources. The establishment of these structures could enormously support such countries in their development and make them part of the global market (Kakissis 2018). At the end of this paper, we present a case study about two cities on these critical trade corridors, Hong Kong and Durban in South Africa.

The authors have provided good practice, i.e. comparing ports and airports of two emerging countries. There is not much literature about either in emerging countries, and especially no comparisons. There is much more in the literature about that issue in developed countries, so this paper's importance is that it collects data from emerging countries' ports and airports and compares them. Therefore, the professional relevance of the paper is that it determines the reasons for the different development in these countries and recent numbers in the industry.

The two goals and the assumptions that will help to provide good practice are the following:

- What is the importance of ports and airports in the development of emerging countries? Here the authors assumed that trade is essential for development, and infrastructure 
Table 1 Comparisons of Ports

\begin{tabular}{lll}
\hline Item & Durban & Hong Kong \\
\hline TEU & 6 million & 18 million \\
Container dwell time & 3-4 days & $1-3$ days \\
Average turnaround time & 50 hours & 10 hours \\
Total cargo handled (int) & 81.2 million & 258 million \\
Revenue (in $€$ ) & 410 million & 2.9 billion \\
Port-related jobs & 100,000 & 83,000 \\
\hline
\end{tabular}

Opombe KPI from 2018. Based on International Transport Forum (2014) and China Merchants Ports Holding Company (2019).

is one of the most expensive ones compared to others. The total port pricing is around 280 USD per TEU compared to Hong Kong, with approximately 230 USD per TEU. The terminal handling charges and cargo dues are the most relevant ones (International Transport Forum 2014) (figure 2).

Another important KPI is container dwell time, as it describes how long a shipping container stays at a port terminal. In the Hong Kong port, the short dwell time of 1-3 days also helps their efficiency, as the storage yards are already limited (Ducruet, Itoh, and Merk 2014). Durban improved dwell time because systems were in place to allow for prompt clearance and release. The 34 days dwell time in Durban are the fewest in any African port, as the average dwell time in African ports is around 10-14 days (International Transport Forum 2014).

The next KPI is the average turnaround time (АТ T). In 2018, ships spent a median time of 23.5 hours in a port. A shorter time in port is a positive indicator that could signal port efficiency and trade competitiveness (UNCTAD 2020). Within this KPI, there is a massive difference between Durban and Hong Kong. Whereas Hong Kong has a short turnaround time of approximately 10 hours, Durban's average turnaround time is much higher than 50 hours (Ducruet, Itoh, and Merk 2014; International Transport Forum 2014).

Both ports contribute massively to the economy of the country, as the Hong Kong port contributes $1.1 \%$ of the gross domestic product in Hong Kong, and the port in Durban contributes between $1.5 \%$ and $2 \%$ of national gross domestic product (The Official Website of the eThekwini Municipality n.d.; Transport and Housing Bureau 2021). Adding to that, they also employ many people and help to reduce unemployment. Port-related jobs in Durban add up to 100,000 people employed in this sector, while in Hong Kong, there are only 83,00o people employed (International Transport Forum 2014). These jobs include workers from the port, but also employees of agents who work there. This means Hong Kong is much more efficient, with fewer people employed in port-related jobs. They achieve much more revenue, handle more cargo, and are more efficient in container dwell time and average turnaround time. The port employees in Hong Kong handled three times more TEUS and more than three times as many tons as Durban did. Furthermore, they are five times faster in turnaround time and 1-2 days faster in container dwell time. This efficiency could be due to various causes like higher automation and merely the size of the port. Nevertheless, the port in Durban will play a vital role in the future economic success of South Africa.

\section{Airports}

Durban's new airport, King Shaka Airport, was opened in 2010 due to the football world cup in South Africa. It has a capacity of 7.5 million passengers annually and has a longer runway, meaning that now, the giant planes such as the Airbus 380 or Boing 747 can land and take off in Durban, which was not possible at the old one. This means that Durban is also considered a medium airport, classified with 5-10 million passengers per year. The airport in Hong Kong was opened in 1998 as the old airport got too small. It is now considered a mega airport that handles more than 30 million people annually. However, the airport even exceeds this by far, with around 71.5 million passengers per year.

Airports can generate revenue in three significant areas: aeronautical revenue, non-aeronautical revenue, and non-operating revenue ('How Do Airports Make Money?' n.d.).

The revenue development of Durban and Hong Kong is visible in figure 3 and figure 4, respectively. It is no surprise that Durban tripled their revenue due to the new airport and the capacity to handle the most prominent aircraft for international flights. Hong Kong almost doubled their revenue, because it is one of the busiest airports globally, handles many freight aircraft and the numbers of passengers are steadily increasing. In this area, Hong Kong outperforms Durban massively with $€ 1.8$ billion generated in revenue compared to Durban's $€ 35.4$ million (Airport Authority Hong Kong 2020; Airports Company South Africa 2020). Therefore, it is essential to read the 


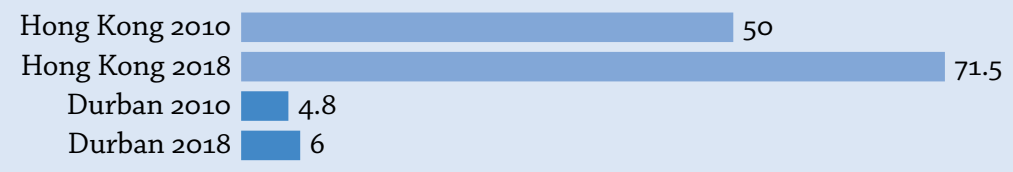

Figure 7 Number of Annual Passengers in Millions (based on Airport Authority Hong Kong 2020 and Airports Company South Africa 2020)

Hong Kong 2010
Hong Kong 2018
Durban 2010
$\begin{aligned} & \text { Durban } 2018 \\ & \text { Figure } 8\end{aligned}$
$\quad$ Number Annual Air Traffic Movements in Thousands (based on Hong Kong International Airport n.d.b and
Airports Company South Africa 2020)

movements per year and two runways in operation (Hong Kong International Airport n.d.a). In Durban, air traffic movements slightly declined, which is an interesting fact. This means fewer regional flights but more international flights with larger aircraft with more seats for passengers (figure 8).

As a medium airport, Durban has an on-time performance of $84.3 \%$ compared to the mega airport in Hong Kong with $76.4 \%$ (OAG Aviation Worldwide 2020). Considering the size of both, these times are quite good, as it is expected that smaller airports are more punctual than bigger ones.

\section{Conclusion}

In conclusion, it can be said that infrastructure is very important for a country's economy, and ports and airports contribute to the gross domestic product and reduce unemployment. Of course, the size is essential, but there is more to mention. Key performance indicators like container dwell time, average turnaround time, or total cargo handled are essential. In most of these indicators, Hong Kong outperforms Durban massively, as they work more efficiently with fewer people employed. Furthermore, the port in Durban has much higher fees for the same amount of cargo than Hong Kong and therefore is not very attractive for many shipments. However, even though Durban is nowhere near the size of Hong Kong, the port and airport are essential for their economy, and they keep improving. Both cities have ambitious plans for the future, leading them in the right direction of becoming more developed.

It was challenging to find good papers and data for both cities' ports and airports, especially Dur- ban. Therefore, we had to abandon our plans to do a correlation analysis. It was impossible to find year-to-year numbers, and it was already hard to find numbers from ten years ago and some recent numbers to compare them and see the development. Furthermore, it was difficult to differentiate the data as they had different definitions. Port-related jobs are an example. Here, it was not easy to differentiate as most of the time the data stated that all jobs which are in any way related to the port or airport are taken into account.

The 21st Century Maritime Silk Road is designed to go from China's coast to Europe through the South China Sea and the Indian Ocean with smooth, secure and efficient transport routes connecting major seaports along the Belt and Road where Hong Kong and Durban are very important hubs. The Maritime Silk Road is the maritime component of China's Belt and Road Initiative (BRI). It complements the various nonmaritime activities stimulated by the Chinese government that relate to transport, energy and communication infrastructure in developing countries, and between China and Europe. It will create better and new opportunities for economic development of both seaports and airports.

\section{References}

AIQ Consulting. 2018. 'Passenger Experience - Why is it Important for Airports?' 6 June. https://www .aiqconsulting.com/aiq-news/passenger -experience-why-is-it-important-for-airports/.

Airport Authority Hong Kong. 2020. Building for the Future: Annual Report 2019/20. Hong Kong: Airport Authority Hong Kong.

Airports Company South Africa. 2020. 2019 Integrated Report. Johannesburg: Airports Company South Africa.

Airports Company South Africa. N.d. 'Passenger Statis- 
tics.' https://www.airports.co.za/Pages/Passenger -Statistics.aspx.

Beard, J. 2018. 'Can Hong Kong's Port Be Competitive, Given Greater Bay Area Threats?' South China Morning Post, 1 September. https://www.scmp .com/comment/insight-opinion/hong-kong /article/2162201/how-hong-kongs-port-can-stay -competitive-and-ahead.

Beckmann, K. 2019. 'Neuzeit: Entdeckung Amerikas.' Planet Wissen, 19 December. https://www.planet -wissen.de/geschichte/neuzeit/entdeckung _amerikas/index.html.

Bjorndal, R. G. 2017. 'Air and Sea - Global Connectivity that Truly Matters.' Ramboll Group, 13 July. https://ramboll.com/ingenuity/air-and-sea -connectivity-that-matters.

China Merchants Ports Holding Company. 2019. 2018 Annual Report: We Connect the World. Hong Kong: China Merchants Ports Holding Company.

Dube TradePort. N.d. 'Overview Dube Cargo Terminal Is a State-of-the-Art Facility and One of the Most Secure Cargo Operations in Africa.' https:// cargoterminal.dubetradeport.co.za/.

Ducruet, C., Itoh, H., and Merk, O. 2014. 'Time Effciency at World Container Ports.' Discussion Paper 2014-08, International Transport Forum, OECD, Paris. https://www.itf-oecd.org/sites/default/files/docs /dp201408.pdf.

Hong Kong International Airport. N.d.a. 'Overview: Air Cargo.' http://www.hongkongairport.com/en /the-airport/air-cargo/index.page.

Hong Kong International Airport. N.d.b. 'Facts and Figures: HKIA at a Glance.' http://www .hongkongairport.com/en/the-airport/hkia-at-aglance/fact-.figures.page.

‘How Do Airports Make Money?’ N.d. U SF unds. http:// www.usfunds.com/slideshows/how-do-airports -make-money/.

'International Trade: Need, Benefits, and Disadvantages.' N.d. Economics Discussion. https://www .economicsdiscussion.net/international-trade /international-trade-need-benefits-and -disadvantages/11906.

International Transport Forum. 2014. 'The Competitiveness of Ports in Emerging Markets: The case of Durban, South Africa.' International Transport Forum Policy Papers 2, OECD, Paris.

Jimenez, E., J. Claro, and J. Pinho de Sousa. 2014. 'The Airport Business in a Competitive Environment.' Procedia: Social and Behavioral Sciences 111 (5): 947954.
Kakissis, J. 2018. 'Chinese Firms Now Hold Stakes In Over A Dozen European Ports.' NPR. October 9. https://www.npr.org/2018/10/og/642587456 /chinese-firms-now-hold-stakes-in-over-a-dozen -European-ports.

OAg Aviation Worldwide. 2018. On-Time Performance for Airlines and Airports and Top 20 Busiest Routes. https://www.oag.com/hubfs/Free_Reports /Punctuality_League/2018/PunctualityReport2018 .pdf.

Roddey, J. 2020. Atlanta International Named World's Most Efficient Airport. Embry-Riddle Aeronautical University, 15 July. http://news.erau.edu /headlines/atlanta-internationalnamed-worlds -most-efficient-airport.

Rodrigue, J.-P. 2020. The Geography of Transport Systems. 5th ed. New York: Routledge.

Soobramanien, T. Y., and C. Zhuawu. 2014. Infrastructure for Trade Development. Commonwealth Trade Hot Topics no. 105. London: London Commonwealth Secretariat.

The Official Website of the eThekwini Municipality. N.d. 'Port City.' http://www.durban.gov.za/City _Services/Economic_Development/Sector _Support/Port_City/Pages/default.aspx.

Transport and Housing Bureau. 2021. 'Study on the Economic Contribution of Maritime and Port Industry in 2018.' https://www.hkmpb.gov.hk /document/Study_on_Economic_Contribution _of_Maritime_and_Por.pdf.

UNCTAD. 2014. 'Freight Rates and Maritime Transport Costs.' https://unctad.org/system/files/official -document/cimem7_rmt2015_ch3_en.pdf.

UNCTAD. 2020. Review of Maritime Transport 2019. Geneva: United Nations.

White, E. 2018. 'T OC Europe 2018: Hamburg and Rotterdam Lead the Way in call for Data Sharing between Ports.' Next Level Information. June 13. https://www.nextlevelinfo.com/toc-europe-2018hamburg-and-Rotterdam-lead-the-way-in-call-fordata-sharing-between-ports.

Zhang, X., and Roe, M. 2019. 'Port Competition.' In Maritime Container Port Security: The USA and European Perspectives, edited by X. Zhang and M. Roe, 59-85. Cham: Springer. 